\title{
SEARCHING FOR AN APPROPRIATE EFL CURRICULUM DESIGN FOR THE INDONESIAN PLURALISTIC SOCIETY
}

\author{
Suwarsih Madya \\ Universitas Negeri Yogyakarta, Yogyakarta
}

\begin{abstract}
The context of the teaching of English in Indonesia is indeed unique, leading to differences in the ease with which children have access to education. Those with great difficulty in accessing education have been and will be left behind by those without any or with little difficulty. Technology will certainly help in easing those in remote areas. The limited financial capacity, however, has made it impossible to have equity in educational access; the equity problem remains unsolved. Under such a complex environment, a more appropriate curriculum design should be sought. So far the same national standard has to be achieved by children. This paper explores possibilities of having a multi-standards English curriculum design aimed at providing every child to learn according to their abilities and rates of learning. A threelevel standard curriculum is then proposed: the instrumental standard for highly advantaged children, the functional standard for those who are fairly advantaged, and the appreciative standard for those who are disadvantaged.
\end{abstract}

Key words: English, curriculum, design, Indonesian

This paper is written in the context of developing the English curriculum in the decentralized system of education, in which the principles of school-based management shall be applied. In the context of this paper, the spirit of decentralization, democratization, and regional autonomy is to improve the effectiveness of all educational services. The first criterion for such effectiveness is the fulfillment of the target students' learning needs in the true sense. Among the most crucial aspects of the secondary school EFL teaching in Indonesian (henceforth EFLTIN), the students' aspect will therefore take more space in the discussion.

Following the political reform, the major educational reform is the shift from the highly centralized to the highly decentralized system. In this new system, while the Central Government is responsible for serving the needs for uni- 
fying the nation, the districts as autonomous political entities are responsible for serving the needs for the multi-aspect developments of their people. Relating this to the issue of the national content of the curriculum, I would say that the policy of having English as one of the compulsory subjects in secondary schools remains the same, as stated in Ministerial Regulation No. 22/2006 on the Standard of Content.

However, the policy of developing the English curriculum changes with the shift of the management system. While the school used to be the mere executor of the curriculum, it is now required to develop its own curriculum based on the national set framework, standards of content, and standard of graduate (exit) competencies. Since the development of school curriculum is a new endeavor for the school, a reference is needed so that the school can accomplish its mission successfully.

The aim of this paper is to search for an appropriate design which will be an easy reference for those who are assigned a task to develop the English curriculum, of which the implementation ensures that all students' progress in accordance with their talent, interest, and ability or rates of learning as mandated in the 2003 Education Act (Article 12). I strongly believe that the teaching and learning of English in secondary schools will be effective if the learning needs of the students, who should be treated as the subjects of learning, are highly considered in making any decisions concerning secondary schools EFLTIN, starting with those made on the curriculum design. Their characteristics should therefore be described in conjunction with other aspects of EFLTIN.

\section{ASPECTS OF SECONDARY SCHOOL EFLTIN}

The English curriculum for secondary schools should be developed in the framework of implementing the national educational system in a wider sociocultural and political context. The curriculum should be aimed at facilitating the development of the potentials of the target students whose characteristics should therefore be considered in the choice of its design. As the implementers of the curriculum, secondary school teachers of English will be another important aspect to be discussed. The process of teaching and learning needs the support of learning resources, which will still be another important aspect in our discussion. 


\section{The Socio-Cultural, Geographical, and Political Context}

The context of the teaching of English in Indonesia is indeed unique in many ways. This has been to a great extent attributable to the multicultural and multilingual nature of our Indonesian society, in which we can easily identify differences - in language, ethnicity, and culture to mention a few. We can find more than 700 local languages and dialects with their own characteristics and about 350 ethnic groups and tribes, with their own customs, types of villages, social structures, beliefs and religions. Political aspirations and expectations also vary as reflected in the number of political parties registered in the 2004 General Election. Throughout South East Asia, Indonesia probably has the greatest diversity of culture, caused by differing histories of the people's contact with and responses to the outside world (Geertz, 1967). With all of these differences, however, we realize that we are one, being united by being "Indonesian", recognizing Indonesia as our only home water-land and Bangsa Indonesia our only nation, and esteeming highly Bahasa Indonesia as our only unifying language, as stated in the 1928 "Youth Oath" long before we got our independence. All of this is clearly expressed in our national motto "Unity in Diversity."

The status of Bahasa Indonesia or the Indonesian language as the State Language has contributed to the uniqueness of the context of EFLTIN. This is further made more unique by the fact that a lot of children have learned to read Arabic before learning English, in some cases even before learning to read Indonesian. In short, in most cases, Indonesian children may have learned at least two languages when they begin to learn English, i.e. their local languages and Bahasa Indonesia.

Such a multicultural/multilingual environment may, on the one hand, facilitate ELFTIN, but on the other, interfere with it. The pluralistic nature of our society requires that we tolerate differences in order to establish a peaceful and harmonious life. We have to understand each other's customs and ways of thinking. We have to understand that what makes one group happy may disappoint other groups. What is regarded as important by one group may be regarded as trivial by other groups. What is regarded by one group as sacred may be regarded ordinary by other groups. And so on, and so on. In this context, our empathy and tolerance of ambiguity develop relatively naturally. I believe these two factors may, as maintained by Brown (2000), facilitate the EFLLIN (EFL learning in Indonesia). However, the students' mother tongues and Bahasa Indonesia may have interfering effects on it. Since the local languages are differ- 
ent from one another and from Bahasa Indonesia, and geographical mobility is greatly possible, the interfering process may be complicated.

Such a context is made more unique by disparities of development resulting from the differing degrees of ease with which people have access to information and development due to geographical conditions, which vary from one area to another. We inhabit about 930 islands out of more than 17,000 islands in the archipelago which spread across the seas for 5,110 kilometers (3,194 miles) east to west and 1,888 kilometers (1,180 miles) north to south. Many of the islands contain rugged mountains and dense jungles that have separated tribal ethnic groups over the centuries. Geographical conditions such as these pose great problems of communication and transportation. As a result, people have different rates of development and different needs of expressions, which have to be considered in making decisions about the curriculum.

It is true that nowadays, advancements of information and communication technology have helped a great deal in improving the above said situation, yet the problems remain unsolved, especially in the remote areas. I have observed two types of remoteness: physical and psychological. A physically remote area is that in areas which are separated by dense forests, swamps, and mountains or seas from the rest of the world. In these areas, people are deprived of access to information and education, and schools, due to delivery problems, cannot be easily equipped with textbooks, curriculum guidelines and laboratories as well as other facilities. Certain schools in isolated areas are seldom, if ever, visited by their supervisors/superintendents and their staff members rarely have the opportunity to attend in-service education. This has been worsened in most cases by young teachers' reluctance to take up teaching appointments in these areas. This has partly resulted in the mismatched teaching assignment. Meanwhile, a psychologically remote area is that in which people are physically in urban areas but they are greatly constrained to access information and development because of their powerlessness due to their socio-economic conditions. Formal education services are available to them, but they cannot afford to send their children to schools. All of this seems to have resulted in disparities of development, which implies different development/learning needs of the related students.

The climate is another factor to be considered. Tropical heat, high degrees of humidity and salty wind do no good to the maintenance of the school hardware and software such as radio, audio-visual aids, computer hardware, and laboratory equipment. Due to financial constraints, only very few schools manage to provide air-conditioned rooms to store the equipment/materials. This has 
to some extent contributed to the disparities in educational achievements in general and EFLLIN achievements in particular, which have in turn contributed to the disparities in personal and social development.

Another aspect which might have impact on EFLTIN is the political system, which has shifted from the highly centralized to highly decentralized one since Law No. 22/1999 (revised in 2004) was promulgated valid in 2001. This has given the district full autonomy in providing primary and secondary education. In relation to EFLTIN, differences may occur in the policy of teaching English to primary schools children. This international language is taught in primary schools in a number of districts, either to all the graders or $4^{\text {th }}-6^{\text {th }}$ graders only. Since no teachers of English have been specially trained and educated for primary schools in the true sense, and only a few schools can afford to hire qualified teachers of English, disparities of quality must have occurred in primary school EFLTIN, which will have great impact on secondary school EFLTIN.

In this unique context, the students certainly have different EFL learning needs which should be considered seriously by any policy makers, including EFLTIN curriculum policy makers if the goal of EFLTIN is to be successfully reached. However, as has been stipulated in the Government Regulation No. 19/2005 on National Standard of Education, of which the implementation of the Exit Competency Standards has been formulated in Ministerial Regulation No. 23/2006, every student is required to have reached the same standard of English competency upon completing their secondary school study. Within the current situations and conditions, this is something probable but impossible to achieve. Only if all the eight national standards of education (of content, process, exit competencies, educational personnel, facilities and equipment, management, financing, and educational assessment) are met by every school will this requirement be possibly fulfilled.

The fulfillment of the national standards of education is currently constrained by our national financial condition. This is partly reflected in the fact that our country cannot afford yet to fulfill our constitutional mandate to allocate $20 \%$ of the national budget to education; in 2006 the educational budget was only about half of it. The fact that natural disasters often hit our country has discouraged me to expect that all schools manage to fulfill seven of the eight national standards mentioned above in 2012 and the standard of educational personnel in 2020. It is this situation which has stimulated me to explore possibilities of having a multi-standards English curriculum design aimed at providing 
every child to learn according to their abilities and rates of learning in their own environments. This design will be a possibility in the context of developing the school level curriculum, which is to be fully implemented by 2009 as announced through television in August 2006 by the Ministry of National Education. The design I am going to propose will fit very well the education system mandated by the 2003 Education Act.

\section{The Education System}

As has been touched upon in the previous section, in the decentralized system of government the provision of basic and secondary education is delegated to the regional government and its implementation is regulated by the 2003 Education Act. This Act stipulates that the provision of basic and secondary education becomes the responsibility of the district government in coordination with the provincial government, with the Minister of National Education remaining responsible for national education. Under this decentralized system, four crucial points are worth mentioning in the context of this paper: (1) the implementation of school-based management (the Education Act, Article 51); (2) the development of school level curriculum based on the national standards yet to suit the needs of each educational unit and learners (the 2003 Education Act, Article $36 \& 38$ ); (3) the final examination for primary, junior secondary and senior secondary education, consisting of two types: the national level examination and the school level examination; and (4) English as one of the subjects in the national examination for junior and secondary education.

One point worth mentioning again here is that students should be treated as the subjects of education and learning. Since EFLTIN is an integral part of our national education system, this should be considered in the development of EFLTIN, of which the curriculum is a crucial aspect. When students are subjects in the education process, they will learn well if the standards to reach are within their levels of capacity in the context of their life. Let us see who the students are.

\section{The Students}

The Indonesian education system is indeed a huge one. Of about 50 million students to serve, more than 29 million are enrolled in primary schools (both general and Islamic), more than eleven million in junior secondary schools (both 
general and Islamic), around six million in senior secondary schools (both general and Islamic), and the rest in higher education institutions. Considering the background described above and seen from the required standards of education, most of the students study in schools which are still below the required standards (see No. $4 \& 5$ below). Those coming from the highly advantaged families may have enjoyed higher quality education since the beginning than those from the fairly disadvantaged ones. Those from the disadvantaged families, however, may have been deprived of even average quality education. The most disadvantaged ones, whose number is reported to reach around three million every year, are those who drop out from primary schools due to socio-economic and cultural reasons. The students live in different environments and come from families with different sosio-economic conditions and therefore reach different levels of development as has been described before. The question is "Is it fair to expect all students to acquire the competencies of the same standards, which, for the core subjects, are measured through the same examination?"

Referring to the goal of national education formulated in Article 3 of the 2003 Education Act, the students should be given ample opportunities to develop their whole potentials - ethics, aesthetics, logic, kinesthetic, or their multiple intelligences, to borrow Gardner's (1995) term. In our Indonesian context, they should develop their spiritual intelligence, their emotional intelligence, their intellectual intelligence (IQ), and their kinesthetic intelligence to be the desired total persons. This will indeed be advantageous for them since all of them will have their places when, as mandated by the 2003 Education Act, they learn according to their talents, interest, abilities in their own environment. If due attention is given to the development of the whole potentials, with achievements in different domains of learning being equally appreciated, no one will feel marginalized in the learning process so that everyone will have the opportunity to be $\mathrm{him} / \mathrm{herself}$. This is an important point for the development of strong personality or identity.

Seen from their personal growth, which will provide the base for their existence, Indonesian students need to develop at least three layers of identity. The first layer is developed in their local cultural context, with their mother tongue being the main means of communication, both intrapersonal and interpersonal. The second layer is developed in their national cultural context, with Indonesian being the main means of communication. The third layer is developed at the international cultural context, with a foreign language, probably mostly English, as the main means of communication. Upon completing secondary schooling, 
students might have developed their identity, with the first layer being highly solid, the second being averagely solid, and the third being basically developed provided that the teaching and learning situations are equally conducive.

Most teaching and learning situations and conditions, however, are still far from being conducive. Though education reform has been mandated by the 2003 Education Act, the teachers tend to put too much emphasis on the cognitive aspects because they have not been trained well enough in facilitating their students' personal developments. In-service teacher training programs have been in place but such programs have not reached all teachers whose number exceeds 2.5 million (Ministry of National Education, 2005). This has been worsened by the washback effect of the national examination on the curriculum implementation, which is so strong that teachers tend to ignore non-academic learning matters. As a result, the students' personal development receives very little attention, if any at all. In this case, children with low academic ability will be most disadvantaged because academically they will never be able to compete with more academically advantaged ones, yet they are deprived of the opportunity to develop personally. Considering that the nine-year basic education is every citizen's constitutional right, this is certainly too important matter to ignore.

To help improve the situation, the English curriculum has to be redesigned so as to ensure that the learning of English will not hamper the students' personal development; instead, it will support it. The design would make it possible for students to learn according to their talents, interests, ability and rates of learning.

\section{The Teachers}

Teachers as professional staff are the heart of the operation in schools. Money, materials, time, space, physical resources and curricula are all important, but during the whole process of learning the ability of the staff to perform is crucial (Harris, 1980). Schools, in contrast to an automated operation, are heavily dependent upon human performance for nearly every aspect of their operation. School personnel, particularly teachers and principals, are a vital link in improvement efforts and at the level of classroom practice, teachers are significant, if not paramount players (Crandall, 1983). In their synthesis and critique of research on effective schools, Purkey and Smith (1982) concluded that "change will not take place without the support and commitment of teachers." 
All of this also applies to secondary school EFLTIN teachers though the challenges they are confronted with seem to be heavier, especially if the requirement of educational qualification is to be fulfilled. That is, all teachers are required to have a first higher education degree or a Diploma-IV. The data presented in Table 1 below already imply the magnitude of the challenge, and with the educational requirements stated in Government Regulation No. 19/2005 on National Standards of Education, the magnitude certainly rises.

Table 1: Data on Secondary School EFLTIN Teachers' Qualifications ${ }^{1)}$

\begin{tabular}{|c|c|c|c|c|}
\hline \multirow{2}{*}{} & \multicolumn{2}{|c|}{ Qualified } & \multicolumn{2}{c|}{ Under-qualified } \\
\cline { 2 - 5 } & $\begin{array}{c}\text { Appropriate } \\
\text { Major }\end{array}$ & $\begin{array}{c}\text { Mismatched } \\
\text { Major }\end{array}$ & $\begin{array}{c}\text { Appropriate } \\
\text { Major }\end{array}$ & $\begin{array}{c}\text { Mismatched } \\
\text { Major }\end{array}$ \\
\hline JSS $^{2)}$ & 12,363 & 2,694 & 11.197 & 949 \\
\hline GSSS $^{3)}$ & 6,668 & 749 & 1520 & 135 \\
\hline
\end{tabular}

Note:

1. This is based on the old regulation, which states that the minimum educational qualification required of JSS teachers is a two-year college/university teacher education, while that of SSS teacher is a threeyear college/university teacher education. The new regulation, i.e. Government Regulation No. 19/2005 requires that teachers of all levels of education hold the first university degree or Diploma-IV teaching certificate.

2. JSS refers to junior secondary schools

3. GSSS refers to General Secondary Schools

Based on the data presented in Table 1, it can be inferred that the teachers of secondary school EFLTIN have too a heavy responsibility to reach the specified standards of competencies. Many of them might have a low level of English proficiency and also be weak in (communicative) teaching methodology. While it is impossible to upgrade their education and teaching skills in the near future, something has to be done to improve the situation, especially seen from the students' potential development. Redesigning the curriculum is one way to improve it. 


\section{Learning Resources}

EFLTIN certainly needs the support of learning resources, which include student textbooks, other curriculum materials, and English input from the environment. The new policy on student textbooks emphasizes the efficiency of textbook use. Education Ministerial Regulation No. 5/2005 on the Use of Textbooks states that textbooks shall be used for at least five years before they are revised. The sad fact is that English textbooks used in secondary schools still need improving in terms of grammar and cultural sensitivity. In his study of fourteen textbooks used in secondary schools, Collins (2005) concluded as follows

The textbooks do not always provide accurate information about the details of English usage, and this is likely have a negative impact on the accuracy of both the teachers' and the students' knowledge of English structure and use. .... there is evidence of an inadequate treatment of the fundamental relationships between form and meaning, and between class and function, and - most alarmingly - many straightforward factual errors. English teachers and educators in Indonesia therefore, it would seem, need to cultivate a critical stance in assessing the quality of grammar presentation when selecting and using textbooks (Collins, 2005: 288).

In her study of textbooks used in Indonesian high schools, Anita Lie (2001) found that the textbooks are not yet sensitive and responsive to varied sociocultural backgrounds of the students in relation to gender, ethnicity, geography, and socio-economic status. As the Indonesian nation is socio-culturally diverse and its communities live in different geographical environments, the findings deserve serious consideration.

To support the development of students' learning, reading materials other than those presented in textbooks are necessary. However, only very few schools have a library with an adequate collection of English readings.

One development which is worth noting is that most Indonesian students can now enjoy English radio and TV broadcasts. However, it all depends on the teachers whether their students are encouraged to benefit from such broadcasts for purposes of improving their learning achievements. 


\section{STANDARDS OF CONTENT AND EXIT COMPETENCIES AND THEIR IMPLICATIONS}

\section{The Standard of English Content}

Referring to Education Ministerial Regulation No. 22/2006 on the Standards of Content, English is one of the compulsory subjects taught in junior secondary schools or Sekolah Menengah Pertama (SMP hereinafter) and Madrasah Tsanawiyah (MTs hereinafter), general senior secondary schools or Sekolah Menengah Atas (SMA hereinafter) and Madrasah Aliyah (MA hereinafter), vocational senior secondary schools or Sekolah Menengah Kejuruan (SMK hereinafter), and Islamic vocational senior secondary schools or $\mathrm{Ma}$ drasah Aliyah Kejuruan. Table 2 below presents the amount of time allocated for English teaching.

Table 2: The Number of Periods for Secondary School EFLLTIN

\begin{tabular}{|c|c|c|c|c|c|c|c|c|c|}
\hline \multirow[t]{2}{*}{ No. } & \multirow{2}{*}{\multicolumn{2}{|c|}{ School }} & \multicolumn{3}{|c|}{ No. of Periods* } & \multicolumn{3}{|c|}{ No. of Weeks } & \multirow{2}{*}{$\begin{array}{c}\text { Total } \\
\text { Periods }\end{array}$} \\
\hline & & & $\begin{array}{c}\text { Year } \\
1\end{array}$ & $\begin{array}{c}\text { Year } \\
2\end{array}$ & $\begin{array}{c}\text { Year } \\
3\end{array}$ & $\begin{array}{c}\text { Year } \\
1\end{array}$ & $\begin{array}{c}\text { Year } \\
2\end{array}$ & $\begin{array}{c}\text { Year } \\
3\end{array}$ & \\
\hline 1. & \multicolumn{2}{|c|}{ SMP/MTs } & 4 & 4 & 4 & $34-38$ & $34-38$ & $34-38$ & $308-456$ \\
\hline \multirow{3}{*}{2.} & \multirow{3}{*}{ SMA/MA } & IPS & 4 & 4 & 4 & $34-38$ & 34-38 & $34-38$ & $308-456$ \\
\hline & & IPA & 4 & 4 & 4 & $34-38$ & $34-38$ & $34-38$ & $308-456$ \\
\hline & & Bhs & 4 & 5 & 5 & $34-38$ & $34-38$ & $34-38$ & $476-532$ \\
\hline 3. & SMK & & & & & & & & $440 * *$ \\
\hline
\end{tabular}

*) One period lasts for 40 minutes in SMP/MTs and 45 minutes in SMA/MA/SMK

**) It is the minimum number of periods; the maximum is left with each school

As shown in Table 2, upon completing his/her junior secondary schooling a student is to have learned English for at least 308 periods of 40 minutes each (= 12320 minutes or more than 205 hours. It is taught in four lesson periods/per week in the $7^{\text {th }}, 8^{\text {th }}$, and $9^{\text {th }}$ grades, with each period lasting for 40 minutes and each academic for 34-38 weeks. Considering the above nonconducive situations, this amount of time is too small for the required standard of competencies, especially in the case of disadvantaged students. 


\section{The Standard of Graduate Competencies}

As stated in Government Regulation No. 23/2006 on Graduate Competencies Standards, there are three types of graduate standards: (a) the standards for the educational unit level; (b) the standards for the subject cluster level, and (c) the standards for the subject level. Statements of standards of English are made for (i) junior secondary education units (SMP/MTs/SMPLB/Paket B), (ii) general senior secondary education units (SMA/MA/SMALB/Paket $C$ ) and vocational senior secondary education (SMK/MAK), and (iii) the English subject at the primary, junior secondary, and senior secondary education levels. The statement of standards of the English subject at the primary education indicates that English belongs to the local content subject cluster at this level of education, while at the junior and senior secondary levels to the compulsory subject cluster. Below are the English translations of the statements of graduate competencies.

The statements of graduate competencies are exactly the same for both the educational unit level and the subject cluster level, which are as follows: (1) At the Junior Secondary Education Level: Demonstrate listening, speaking, reading, and writing skills in simple English;(2) At the general senior secondary education level: Demonstrate listening, speaking, reading and writing in English;; (3) At the vocational senior secondary education level: Demonstrate listening, speaking, reading and writing skills in English.

Differences between lower and higher levels of learning are, however, observable in the statements of competencies at the subject level (See Appendix).

When examined carefully, there is no statement on the level of English proficiency for each level of education. The differences between the lower and higher levels of English learning lie in (1) levels of difficulty described through the expressions 'very simple'-'simple', (2) types of texts, with less types for the former level, and (3) the contexts, with the former being narrower. All of this implies differences in the number of vocabulary items and types of expressions to be learned. Ideally, all students are introduced to all types of texts, but in my opinions, texts of certain types such as spoof might be unrealistic for many of our students and their teachers; they are not easy to find and/or create and the degree of usefulness is low. Some freedom should therefore be given to teachers to find alternative texts to make learning more meaningful to students, who vary in their linguistic, cultural, and socio-economic background and in access to information. Such freedom may be exercised in the model of curriculum development proposed below. 


\section{IMPROVING THE SITUATION THROUGH A CURRICULUM DE- SIGN THAT BENEFITS EVERY STUDENT}

\section{Foundations of the Proposed EFLIN School Curriculum}

The EFL curriculum design should be developed based on solid foundations. As part of the education programs, EFLTIN should be conducted in the spirit of implementing the 2003 Education Act. A number of provisions in this Act are relevant to be referred to here. First, EFLTIN should be implemented in reference to the principles of providing education stated in Article 4 of the 2003 Education Act of which the English version is quoted below:

(1) Education is conducted democratically, equally and nondiscriminatorily based on human rights, religious values, cultural values, and national pluralism.

(2) Education is conducted as a systemic unit with an open system and multi-meanings.

(3) Education is conducted as a life-long process of inculcating cultural values and for the empowerment of learners.

(4) Education is conducted based on the principles of modeling, motivation and creativity in the process of learning.

(5) Education is conducted by developing culture for reading and writing, and arithmetic, for all members of the community.

(6) Education is conducted by empowering all components of the community through their participation in the implementation and quality control of the education services.

Secondly, EFLTIN should ensure, as has been touched upon previously, that "Every learner in an educational unit is entitled to obtain education services in accordance with his/her talent, interest, and ability" (Article 12, The 2003 Education Act). In this case, learners with special needs due to their limited ability should also be catered for; so should those with exceptionally high ability. This can be achieved by implementing a curriculum with levels of standards. Thirdly, the curriculum at all educational levels and types of education should be developed according to principles of diversifications, adjusted to the units of education, local and learners' potentials (the 2003 Education Act, Article, 36). This implies a possibility of having a curriculum with different levels of stan- 
dards considering that districts and learners vary in potentials. It can then be said that a school English curriculum can be developed to fulfill the students' learning needs. I assume that learning needs can be fulfilled when (1) the level of difficulty of tasks suits the level of students' ability, (2) the learning materials and tasks are meaningful to students, and (3) students enjoy freedom to express themselves because they are empowered.

\section{Definition of Curriculum}

Different definitions of curriculum have been proposed, for example by Tyler (1949), Wheeler (1967), Eisner (1979), Skilbeck (1984), and Print (1993). For the purposes of this paper, the term 'curriculum' means the statements of competencies to be acquired by learners in their own learning environment and all the planned learning opportunities offered to learners and the experiences learners encounter when the curriculum is implemented. This concept will be translated into a curriculum design described below.

\section{The Need to Search for an Appropriate Curriculum Design}

\section{a. Necessary Levels of Standards}

The background data on Indonesian children aforementioned imply necessary great wisdom of seeing their learning needs, which in this context, would be viewed from two angles. The first angle is concerned with the development of their identity and the second with the development of their potentials.

It has been touched upon previously, as members of the Indonesian multicultural society, all Indonesian children need to develop a three-layer identity, with the first layer to be developed within their local cultural context largely through the use of their mother tongues, the second layer within their national cultural context through the use of the Indonesian language, and their third layer within their global context largely through the use of English and/or other foreign languages. The first layer functions as the taproot for the other two so that if it develops properly and solidly the whole three-layer identity will be solid and strong too. Every child has the right to develop his/her first layer identity properly. This is their very learning need to be fulfilled at the basic education level to pave the way for their future success. Next will be the second layer identity of 
which the development will take place while the first layer is also still in the process of solidifying; the two processes are to some extent overlapping. The overlap will continue to include the development of the third layer identity when they turn to thirteen at entering the junior secondary schools for most children, but for some thousands of children the three layer overlapping processes take place at earlier age when they begin to learn English in the fourth grade of primary schools, and some at even earlier age when they enter primary schools. In short, every child has the right to develop the first layer identity, is obliged to develop the second layer, and is recommended to develop the third layer.

Concerning the development of their potentials, children vary in talents and rates and capacity of learning. Some are very fast learners, some are very slow learners, and most of them are probably learners with an average rate of learning. Whether they will have their true rate of learning, it will depend on the resources available for them. In some cases, children are highly advantaged by their high ability and abundant financial resources as well as a conducive learning environment so that they enjoy their true rates of learning. In most cases, children are fairly advantaged by their ability, modest financial resources, and modest learning environment so that they might learn at the speed less than their true potential speed. In some other cases, children are disadvantaged in all the three aspects so that they might learn at the speed much lower than their true speed. The first two groups can certainly be expected to reach the national standard of graduate competency, with the first even beyond it. The third group, however, can only suffer if they are expected to reach the national standard given their situations and conditions. Considering the tendency of teachers to pay so much attention on the national examination subjects that other subjects are overlooked, this group will be deprived of proper development. It is impossible for them to compete with their luckier fellow students in the national examination subjects and other more academic subjects, while non-academic and/or non-national examination subjects are not given due attention. Since every child is entitled to obtain education services in accordance with his/her talent, interest, and ability, and to complete an education program based on individuals' rate of learning and not exceeding the time determined (the 2003 Education Act, Article 12b and 12f), wise decisions should be made for them. In the context of this paper, wise decisions leading to an appropriate policy of the EFL curriculum, are indeed obligatory.

For purposes of providing appropriate EFL instructional services within the existing constraints, Indonesian children, as has been mentioned earlier, may be 
grouped into three: (a) the highly advantaged children, (b) the fairly advantaged children, and (c) the disadvantaged children. When time, for practical reasons, is held relatively constant, it is unfair to expect them all to reach the same standard, especially at the level of basic education, which is every child's constitutional right, as stipulated in the 2003 Education Act (Article 34). The approximately appropriate standard should therefore be formulated for each group while still giving them opportunity to move between standards when occasion permits or demands. The most important thing to be emphasized here is that all of them will be able to develop their potentials comfortably and appropriately as Indonesian citizens in their own environment. This is a particularly crucial point as far as basic education is concerned.

In this context, three levels of standards will be proposed: the instrumental standard, the functional standard, and the appreciative standard. These three interrelated standards will be incorporated in a curriculum design to be described in Section c below. This design is intended for secondary EFLTIN, with special attention given to junior secondary education as part of the nine-year basic education, which, as has been mentioned before, is every child's constitutional right.

\section{1) The Instrumental Standard}

This standard is intended for those who are highly advantaged, i.e. those who, as has been mentioned before, have enjoyed great economic and intellectual advantages as well as a conducive learning environment. These advantages will contribute significantly to their success of learning English. At this level of standard, the emphasis is on the development of the students' whole communicative competence from which they will benefit a great deal in terms of scholarly and/or socio-economic achievements. They are expected to be able to communicate both orally and in written form, both receptively and productively and orally, and both socially/professionally, and/or academically/ intellectually with a high level of fluency, accuracy, and appropriateness. In short, they are to reach the mastery of communicative English in the true sense.

\section{2) The Functional Standard}

This is intended for those who are fairly advantaged, i.e. those who have enjoyed modest economic and intellectual advantages as well as a fairly condu- 
cive learning environment. The focus is on the development of a sort of threshold level English communicative competence. With this level of competence, they are ready to function fairly well in English in daily life in the real world. Functional expressions should be the focus of learning. With this standard, they communicate effectively with other people in daily life situations in intelligible and comprehensible English, both interpersonally and transactionally.

\section{3) The Appreciative Standard}

This standard is intended for those who are disadvantaged in all the three aspects mentioned above, i.e. those who are of lesser ability, have limited financial resources, and are plunged into a learning environment which is not conducive to learning at all. The focus is on arousing their appreciation for a foreign culture as reflected in English. Exposing them to functional English will be emphasized, but they are required to master only some English functions relevant to their felt needs. The important thing to accomplish is that they can learn comfortably in English classes and show appreciation for English as a cultural manifestation.

\section{Opportunity to Move between Standards}

As has been touched upon above, students have opportunities to move between standards as illustrated in Figure 1 (over page). As the situation and condition in which children live and learn may change either in the positive or negative direction, meaning that they may enjoy more or less advantages, they are allowed to move between standards depending on their learning achievements. Some of those who at the beginning belong to the instrumental standard group may wish or be recommended to abandon that standard and move to the functional standard group. Similarly, those belonging to the functional standard group at the beginning may move to the appreciative standard group. By contrast, some of those who have entered the appreciative standard group may wish or be recommended to move to the functional standard group, and those who are formerly in the functional standard group may wish or be recommended to move to the instrumental standard group. The opportunity to move is in fact consistent with the multi-exit-multi entry system to be developed as mandated by the 2003 Educational Act, Article 4, as explained in the supplement. 


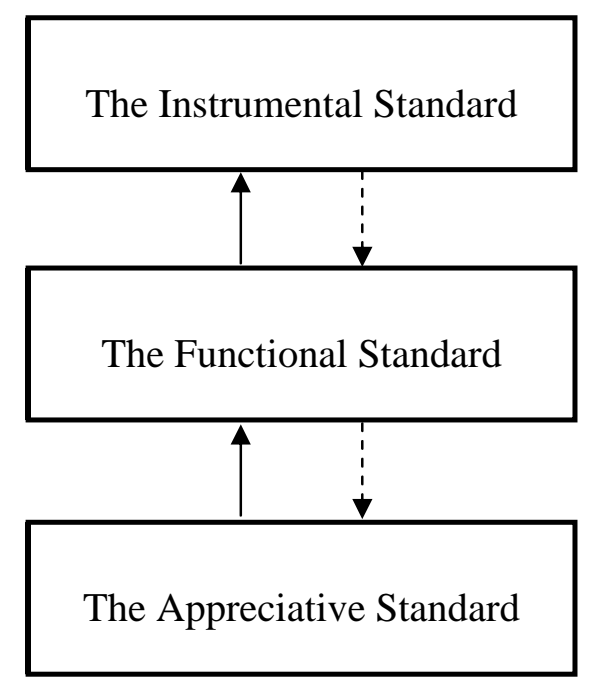

Figure 1: Possibility of Movement between Standards

\section{The Cyclone Model of EFL Curriculum Development}

The development of the three level standards of the EFLTIN curriculum should be guided by a model to ensure the appropriate coverage, selection and sequence of contents. For this I am proposing the 'Cyclone' model, which is in fact a further development of the Kerusil Model I proposed in 1987 (Madya, 1987) and further modified in 1989 (Madya, 1989). 'Cyclone' is an acronym of 'cylinder' and 'cone', the two combined shapes used to illustrate in a unity the framework of selecting and sequencing the content. This model is to ensure that students' needs, characteristics, and target competencies are considered well in the development of the curriculum, as mandated by the 2003 Education Act. See Figure 2 below. For elaborate considerations of choosing this model, see Madya (1989).

As illustrated in Figure 2, the cylinder is used to symbolize the whole content coverage of the curriculum for both junior secondary and senior secondary schools (both general and Islamic). This is to ensure the link the EFLTIN in 
the two levels of schooling. Around a half of the content, represented by the cone, is concerned with things close or familiar to students whose position is symbolized in the centre by a vertical line. The position of the vertical line symbolizes the student-learning-centeredness.

In terms of coverage, the instrumental and functional standards are to cover the whole material, but the former requires higher levels of fluency, appropriateness, and accuracy. These two standards apply to both junior and senior secondary education. However, the appreciative standard, which applies to the junior secondary education as part of the nine-year compulsory education, is to cover about $60 \%$ of the content and requires lower level of accuracy but may be the same level of fluency and appropriateness.

In this model of curriculum development, three hierarchical criteriausability, familiarity, and levels of difficulty - should be integrated in every decision concerned with the selection and sequence of materials, both content and linguistic, by making use of learners' linguistic, socio-cultural, environmental, and educational background (cf. Finnochiaro, 1978). This requires that students' existing knowledge, abilities, and experiences should be used as input in curricular decision making. Considerations of usability are related to the degree of immediacy of using the expressions learned. This might be further related their motivation to express themselves in English. Considerations of familiarity are linked to the degree of familiarity of the things mentioned in the topics to students. This might be related to the ease with which students express themselves in terms of meanings. Another aspect to be considered is the level of difficulty, which is very much related to the students' capacity of learning. All the three criteria may be put into a continuum of 'Rare - Frequent' from the students' point of view, by considering their characteristics and experiences.

The principle of balance is envisaged by the room inside and outside the cone within the cylinder. The balance refers to that between the familiar and unfamiliar things and that between the linguistic and communicative components. The balance is maintained by integrating the things/components concerned throughout the learning processes, with emphasis shifting from one type of practice to another depending on the level of learning and the competencies to be acquired. 

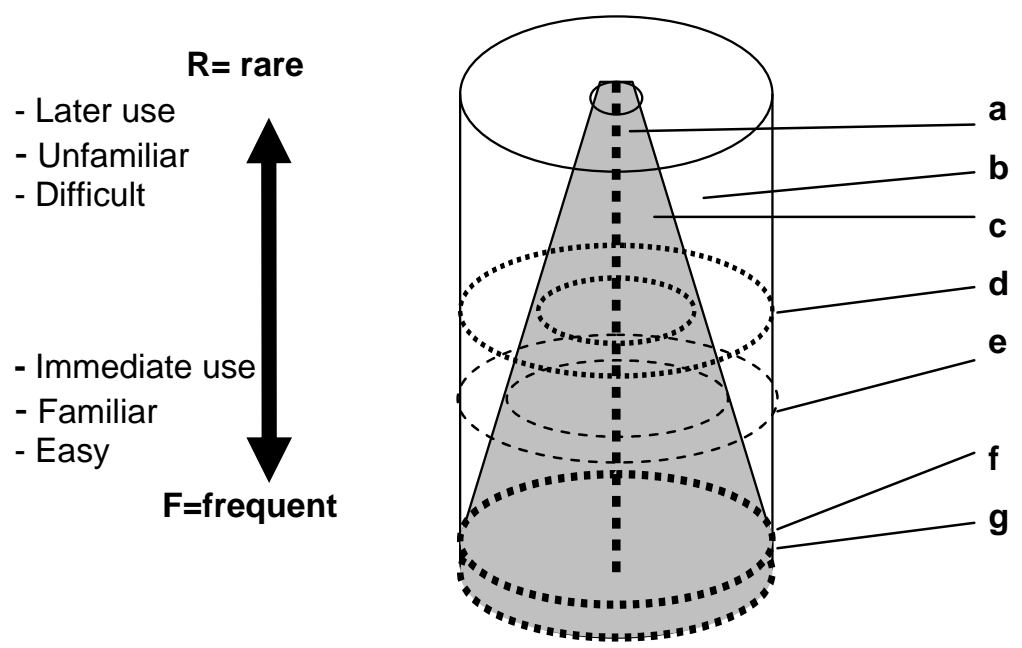

\begin{abstract}
Note:
$\mathrm{a}=$ the vertical line in the middle of the cylinder, representing learners' position;

$\mathrm{b}=$ the area outside the cone, which is not shaded, representing the materials the content of which is mostly about topics of English background;

$\mathrm{c}=$ the shaded cone, representing materials of which the content is about topics or things familiar to students;

$\mathrm{d}=$ junior secondary-senior secondary schooling border;

$\mathrm{e}-\mathrm{g}=$ the appreciative standard

$\mathrm{f}-\mathrm{g}=\quad$ initial stage

$\mathrm{R}-\mathrm{F}=\quad$ Rare-Frequent, in terms of how often the concepts or things concerned are referred to by the students in their daily life
\end{abstract}

\title{
Figure 2: The Cyclone EFL Curriculum Model
}

The shaded area represents the materials familiar to students, i.e. topics they already know in terms of content. Seen from the point of learning, they have learned about the concepts/topics so that they are then to learn English vocabulary items and grammatical structures needed to express themselves about the concepts/topics. It should be noted, however, that the same topics may need different vocabulary items considering that the students' experiences vary with their environments. For example, to express ideas and feelings about their daily life in the surrounding area, students living in big cities will need different words 
and expressions from those living in the valleys and in the slopes of mountains. Variations may be observed between those living in different areas in the city.

By contrast, the area outside the cone, which is not shaded, represents things unfamiliar to students, i.e. things which have not been learned through the language(s) they have mastered. From the point of view of learning, they will learn both the concepts and the English vocabulary items and grammatical structures needed to express them. The most unfamiliar ones are those about foreign people. The higher the level of learning, the more the topics about unfamiliar things and the less about familiar things will be. Such an arrangement will ensure the meaningfulness of learning to the students and this will in turn help improve its effectiveness. (See Brown, 2001, for the principle of meaningful learning).

In this model, the grammatical system serves as the core of the school curriculum to ensure its systematization and the functions are selected to meet the students' learning needs with the topics ordered from more familiar to more unfamiliar ones. It should be stated clearly that in its implementation due attention should be given to accuracy and fluency as well as appropriateness.

As indicated in Figure 2 above, while the instrumental and functional standards are intended for both junior and senior secondary school students, the appreciative standard is intended for the junior secondary school students. This standard may cover about $60 \%$ of the EFL curriculum content of the junior secondary school, with the minimum mastery of, say, $30 \%$. All of this is to ensure that the disadvantaged students can learn within their own situations and conditions with various constraints. In this way, the possibility of losing their confidence, which will in turn hinder their personal development, will be minimized. This is a crucial point to consider since basic education is the only education they will probably attend.

Regardless of the different levels of mastery requirements, the three groups of students are to be provided with an initial stage, of which the period may vary according to the learning needs, ranging from three to six months. At this stage, the emphasis will be on building students' motivation and introducing new things of linguistic nature, which are presented in pedagogically communicative contexts. 


\section{CONCLUDING REMARKS}

Examining carefully aspects of the secondary school EFLTIN, I would say that EFLTIN has its own unique characteristics. For purposes of achieving learning effectiveness within the existing situations and conditions and enabling EFLTIN to contribute to the students' potential development, the three standard model of EFL curriculum development will fit the school level curriculum $(\mathrm{Ku}$ rikulum Tingkat Satuan Pendidikan), which is meant to ensure that the students true learning needs are met. It is certainly my great hope that some schools will adopt the model, while the EFL teacher educators at the university will collaborate with EFL teachers in conducting the collaborative action research about the curriculum development. In this way, both worlds will be brought closer together to minimize the gap between theories and practice.

\section{REFERENCES}

Brown, H.D. 2001. Teaching by Principles: An Interactive Approach to Language Pedagogy. New York: Longman.

Collins, P. 2006. Grammar in TEFL: a Critique of Indonesian High School Textbooks. TEFLIN Jorunal

Crandall, D.P. 1983. The teacher's role in school improvement. Educational Leadership 41, 3, 10-13.

Eisner, E. 1979. The Educational Imagination: On the Design and Evaluation of School Program. New York: MacMillan.

Harris, B.M. 1980. Improving Staff Performance through In-service Education: A Guide to Better Practice. Englewood Cliffs, N.J.: Prentice-Hall, Inc.

Lie, A. 2001. Multicultural issues in the 1994 English curriculum in Indonesian Senior High Schools. In Language Curriculum and Instruction in Multicultural Societies (Eds. W.A. Renandya \& N.R. Sunga). Singapore: RELC.

Madya, S. 2003. Pengajaran Bahasa Inggris di Indonesia: Suatu Tinjauan Reflektif. A professorship oration presented at the Open Senate Plenary. Yogyakarta: State University of Yogyakarta.

Ministry of National Education 2005. Indonesia: Educational Statistics in Brief 2004/2005.

Print, M. 1993. Curriculum Development and Design. $2^{\text {nd }}$ Ed. Sydney: Allen \& Unwin. 
Purkey, S.C. \& Smith, M.S. 1982. Too soon to cheer? Synthesized research on effective schools and educational leadership. Elementary School Journal 40, 60-69.

Skilbeck, M. 1984. School-Based Curriculum Development. Mimeograph.

Tyler, R. W. 1949. Basic Principles of Curriculum and Instruction. Chicago: University of Chicago Press.

Wheeler, D.K. 1967 Curriculum Process. London: University Of London Press. 


\section{Appendix}

(1) At the Primary Education Level: (a) Listening - Understand very simple instructions, information, and stories presented orally in the classroom, school, and surrounding context; (b) Speaking - Express orally meanings in very simple interpersonal and transactional discourse in the form of instructions and information in the classroom, school and surrounding contexts; (c) Reading - Read aloud and understand meanings in the form of very simple instructions, information, short functional texts, and pictured descriptive texts presented in written forms in the classroom, school, and surrounding contexts: (d) Writing - Write words, expressions, and very simple short functional texts with correct spelling and punctuations.

(2) At the junior secondary level: (a) Listening - Understand meanings in simple interpersonal and transactional oral discourses, both formal and informal, in the form of recount, narrative, procedure, descriptive, and report, in daily life contexts; (b) Speaking - Express meanings orally in simple interpersonal and transactional discourse, both formally and informally, in the form of recount, narrative, procedure, descriptive, and report, in daily life contexts; (c) Reading - Understand meanings in simple written interpersonal and transactional discourse, both formally and informally, in the form of recount, narrative, procedure, descriptive, and report, in daily life contexts; (d) Writing - Express in written form meanings in simple interpersonal and transactional discourse, both formally and informally, in the form of recount, narrative, procedure, descriptive, and report, in daily life contexts.

(3) At the senior secondary school level: (a) Listening - Understand meanings in interpersonal and transactional oral discourses, both formal and informal, in the form of recount, narrative, procedure, descriptive, news items, report, analytical exposition, hortatory exposition, spoof, explanation, discussion, and review in 
daily life contexts; (b) Speaking - Express meanings orally in simple interpersonal and transactional discourse, both formally and informally, in the form of recount, narrative, procedure, descriptive, news items, report, analytical exposition, hortatory exposition, spoof, explanation, discussion, review and report, in the daily life contexts;(c) Reading - Understand meanings in simple written interpersonal and transactional discourse, both formally and informally, in the form of recount, narrative, procedure, descriptive, news items, report, analytical exposition, hortatory exposition, spoof, explanation, discussion, review and report, in the daily life contexts; (d) Writing - Express in written form meanings in simple interpersonal and transactional discourse, both formally and informally, in the form of recount, narrative, procedure, descriptive, , news items, report, analytical exposition, hortatory exposition, spoof, explanation, discussion, review and report, in the daily life contexts.

(4) The Language Program: (a) Listening - Understand meanings in interpersonal and transactional oral discourses, both formal and informal, in the form of recount, narrative, procedure, descriptive, news items, report, analytical exposition, hortatory exposition, spoof, explanation, discussion, review, and public speaking in the academic context, and popular and authentic literary works in real daily life; (b) Speaking - Express meanings orally in simple interpersonal and transactional discourse, both formally and informally, in the form of recount, narrative, procedure, descriptive, news items, report, analytical exposition, hortatory exposition, spoof, explanation, discussion, review, report, and public speaking in the academic context, and popular and authentic literary works in real daily life; (c) Reading Understand meanings in simple written interpersonal and transactional discourse, both formally and informally, in the form of recount, narrative, procedure, descriptive, news items, report, analytical exposition, hortatory exposition, spoof, explanation, 
discussion, review, report, and public speaking in the academic context, and popular and authentic literary works in real daily life; (d) Writing - Express in written form meanings in simple interpersonal and transactional discourse, both formally and informally, in the form of recount, narrative, procedure, descriptive, news items, report, analytical exposition, hortatory exposition, spoof, explanation, discussion, review, report, and public speaking in the academic context, and popular and authentic literary works in real daily life. 